\title{
MATHEMATICAL MODELS AND RECOGNITION METHODS FOR MOBILE SUBSCRIBERS MUTUAL PLACEMENT
}

\author{
Vadim V. Ziyadinov, \\ Moscow Technical University of Communications and \\ Informatics, Moscow, Russia, willwillson I3@gmail.com \\ Maxim V. Tereshonok, \\ Moscow Technical University of Communications and \\ Informatics, Moscow, Russia, tereshonok@srd.mtuci.ru
}

\author{
Manuscript received 22 December 2020; \\ Accepted 02 February 2021 \\ Keywords: neural networks, mobile network \\ subscribers' mutual placement types, positioning, \\ classification, shape recognition
}

\begin{abstract}
The challenge of mobile subscribers' groups and crowd's behavior prediction during the mass events is now increasingly important. Operative methods application of this task solution is difficult; accordingly, development and application of technical methods is necessary. The method of this problem solution consists of subscribers' telephone conversations recording in a zone of mass action, and the following speech recognition, the semantic analysis and statistical processing application. However, there is a tendency demand decrease for mobile systems voice services with simultaneous demand growth for data traffic nowadays. The purpose of this paper is to create a mathematical model of mobile networks subscribers' mutual placement types, applicable for automatization of the subscribers' activities nature prediction systems. The research method consists of mathematical simulation model development for pseudorandom examples generation of subscribers' mutual placement types set, creation of training dataset, convolution neural network training and usage of training results to recognize the new examples. The results obtained. A mathematical model is proposed allowing to create a representative training and validation dataset of mobile networks subscribers' mutual placement types for neural network training and testing. The convolution neural network trained using these samples has shown high classification accuracy results with a wide class of subscribers' mutual placement types.
\end{abstract}

Information about authors:

Vadim V. Ziyadinov, engineer, Moscow Technical University of Communications and Informatics (MTUCl), Moscow, Russia Maxim V. Tereshonok, Head of scientific laboratory, Moscow Technical University of Communications and Informatics (MTUCl), Associated Professor, D.Sc., Moscow, Russia

Для цитирования:

Зиядинов В.В., Терешонок М.В. Математические модели и методы оценки взаимного расположения мобильных абонентов // T-Comm: Телекоммуникации и транспорт. 202I. Том I5. №4. С. 49-56.

For citation:

Ziyadinov V.V., Tereshonok M.V. (202I) Mathematical models and recognition methods for mobile subscribers mutual placement. T-Comm, vol. 15, no.4, pp. 49-56. (in Russian) 


\section{Introduction}

The challenge of mobile subscribers' groups and crowd's behavior prediction during the mass events is now increasingly important. Operative methods application of this task solution is difficult; accordingly, development and application of technical methods is necessary. The method of this problem solution consists of subscribers' telephone conversations recording in a zone of mass action, and the following speech recognition, the semantic analysis and statistical processing application. However, there is a tendency demand decrease for mobile systems voice services with simultaneous demand growth for data traffic nowadays [1].

The reason for this is the fact that subscribers are increasingly using so-called messengers' services, social networks and instant messaging programs that use Internet to work. Most messengers use the so-called end-to-end encryption methods of transmitting information messages and speech, based on Diffy-Hellman protocol [2, 3], which makes the group behavior automatic analysis task impossible on the mobile operator layer. It also becomes impossible to identify intercommunicating subscribers' groups, as far as any information about the message recipient is not transmitted in the communication system control channels. In these circumstances it becomes actual to apply automatic analysis methods of service commands transmitted in control channels $[4,5,6,7]$.

It is possible in modern mobile networks to determine the subscribers' location with high accuracy, for example, using several base stations (at the intersection of their service zones, with the distance to base stations determination, etc.), as well as using of satellite-based global positioning systems such as GPS and GLONASS $[8,9,10]$.

In papers $[1,4,11,12,13]$ the general methodological approach to the intellectual analysis of service information transmitted in the mobile communication systems channels for the purpose of mass events participants activity evaluation and forecasting is offered. The proposed approach is based on the subscribers' locations associative analysis in order to identify their stable groups and the subsequent subscribers' mutual placement forms neural network analysis (of the previously determined stable groups members). Such approach $[1,4,5,6,10]$ makes it possible to evaluate the subscribers organized groups behavior even with very dense accumulation, for example, at mass events.

\section{Problem statement}

The paper [1, 8] suggests a method of subscribers' mutual placement types recognition automation, considering the possible errors in the each of these subscribers' location data. In this article [1] six synthetic subscribers mutual placement types were considered, and it was shown that convolutional neural networks can be used for these mutual placement types recognition [14]. Nevertheless, the paper [1] authors have not proposed a subscribers' mutual placement types modeling method that allows to create a wider class of forms and regulate the individual subscriber's coordinates uncertainty parameters.

This article is devoted to the method development of modeling the mobile networks subscribers' mutual placement types that provides the necessary opportunities to vary important parameters such as the value of subscribers' coordinates dispersion relative to the subscribers' mutual placement type base vector model (Figure 1) (to simulate the location determination inaccuracy), the number of subscribers in the examples, the figure position angles.

\section{$0 \times 0 \times 0000$}

Figure 1. Subscribers' mutual placement type vector base model (reference line, blue) - a line or a group of lines describing the subscribers' coordinates mathematical expected value. The points describing the subscribers position have a random offset $\Delta$ off the reference line. The red circles show the subscribers standard deviation $\sigma$ off the reference line

\section{Simulation of mutual placement types}

Special departments employees, performing official tasks, act in groups and in certain order of action [15]. For a simulated in this paper subscribers' mutual placement types (SMPT) the Ministry of Internal Affairs textbooks of security forces tacticalspecial preparation $[15,16]$ were used.

According to [15, 16], 11 types of subscribers' mutual placement were selected. These examples are shown on Figure 2.

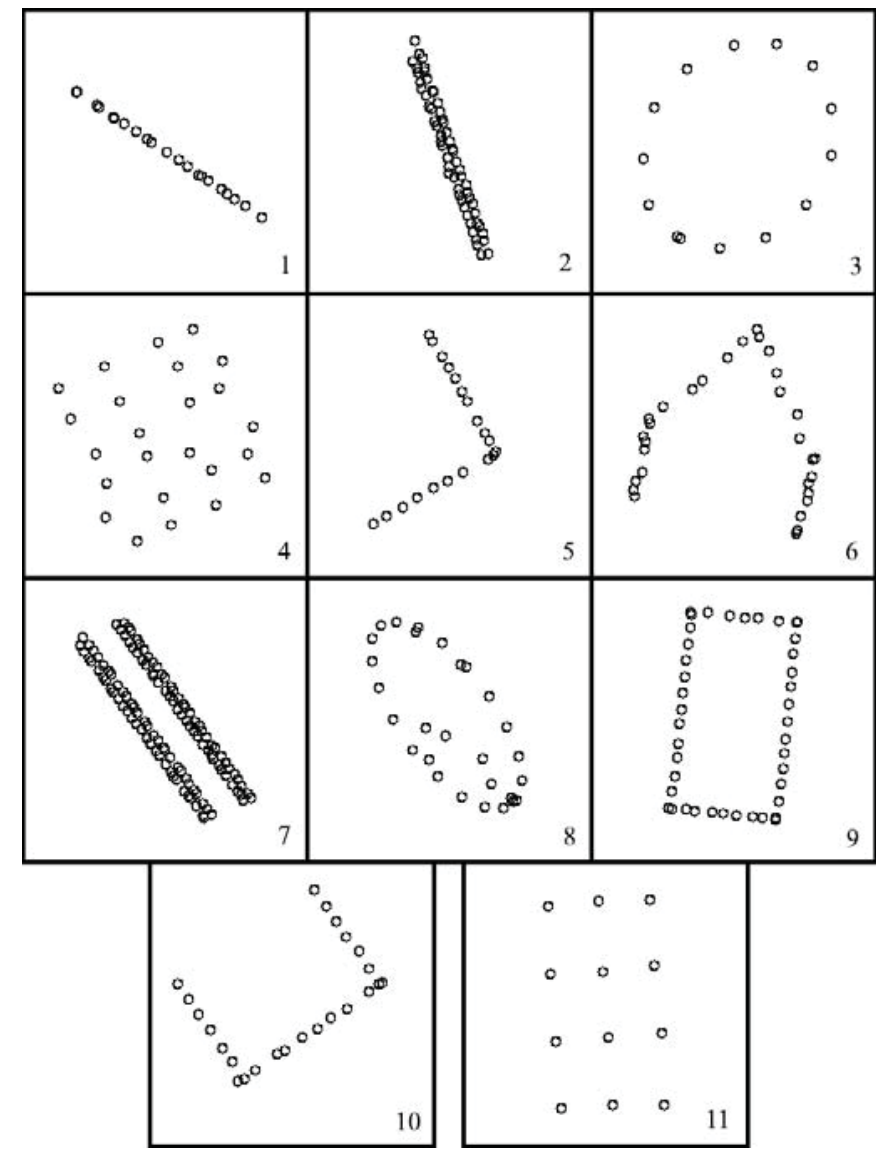

Figure 2. Simulated subscribers' mutual placements types

1. Chain (column) »- the basic formation for following actions, is used for cordoning off the special operation area.

2. Column of two» - used for marching. Participants are lined up in two rows, with the distance between the rows comparable to the distance between subscribers in each row. 
3. Ring» - to isolate active rioters. It may be described as a combat order "Chain", closed in a circle.

4. «Crowd»-the subscribers crowding is chaotic, with no definite shape or direction.

5. Wedge (type 1) » - is designed to cut the crowd of the rioters. The personnel are located in two rows at a sharp angle.

6. Wedge (type 2) " is another variation of the "Wedge" combat order, describes the rows at the sides to protect the personnel.

7. «Corridor» - is used to limit the human traffic on the driveway. Subscribers are arranged in 2 rows of 1-3 lines at some larger distance between the rows, with the distance between the lines is comparable with the distance between subscribers in a single line.

8. «Shuttle» - designed to protect the personnel of a unit crashing into a crowd when there is a threat from the rear, and to retreat to their initial positions.

9. Square»-combat order, a square-shaped structure.

10. «Bowl» - d to partially encircle or to displace rioters. It is a semicircle or three rows at an angle to each other.

11. Turtle» / «fist» - is designed to protect unit personnel from flying objects on top of the unit in narrow crowded streets, or to cut the crowd, taking desired positions within the crowd and evacuate the affected personnel. These combat orders differ only by the actions of the personnel, so they are combined into one.

The developed mathematical model of subscribers' mutual placement types description simulates necessary examples set of these samples with some random points (subscribers) distribution in these subscribers' mutual placement types, random angle of figure orientation (figure 3).

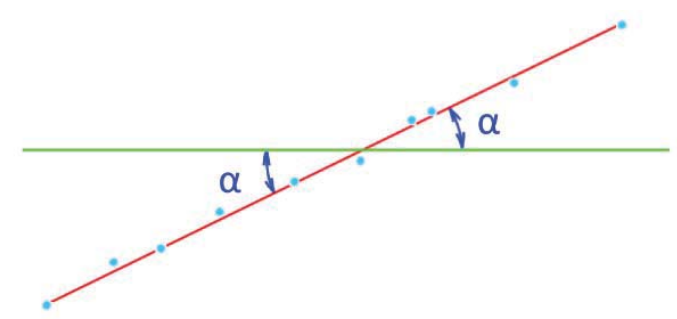

Figure 3. Figure of subscribers' mutual placement type turn, at a random angle $\alpha$ (using the example of "chain" type)

Examples of subscribers' mutual placement types generated using the developed model are presented as an array of $256 \times 256$ elements. This array size was chosen because it provides a sufficiently high resolution, but still compact enough not to affect the array size in the computer memory and the neural network learning rate. As a rule, the distance between individual subscribers in the group is at least 0.5 meters. Accordingly, when analyzing groups of "foot" subscribers, where the highest resolution is required (because in this case the subscribers themselves can be quite close to each other) the image scale is 0.5 meters per one pixel. This resolution is enough to estimate the subscribers' mutual placement type from crowds located on the area of about 1 hectare. The number of pixels in the image is chosen to be equal to a whole degree of 2 for the convenience of the convolution operation implemented by each neural network layer, with this approach, dropping the resolution in each subsequent layer by half.
In the developed mathematical model, the vectors corresponding to subscribers' mutual placement type are described, and the random quantity of the points corresponding to subscriber's positions is generated on these vectors. For this purpose, the points on the vector at regular intervals are created describing the points coordinates array (Figure 4, a).

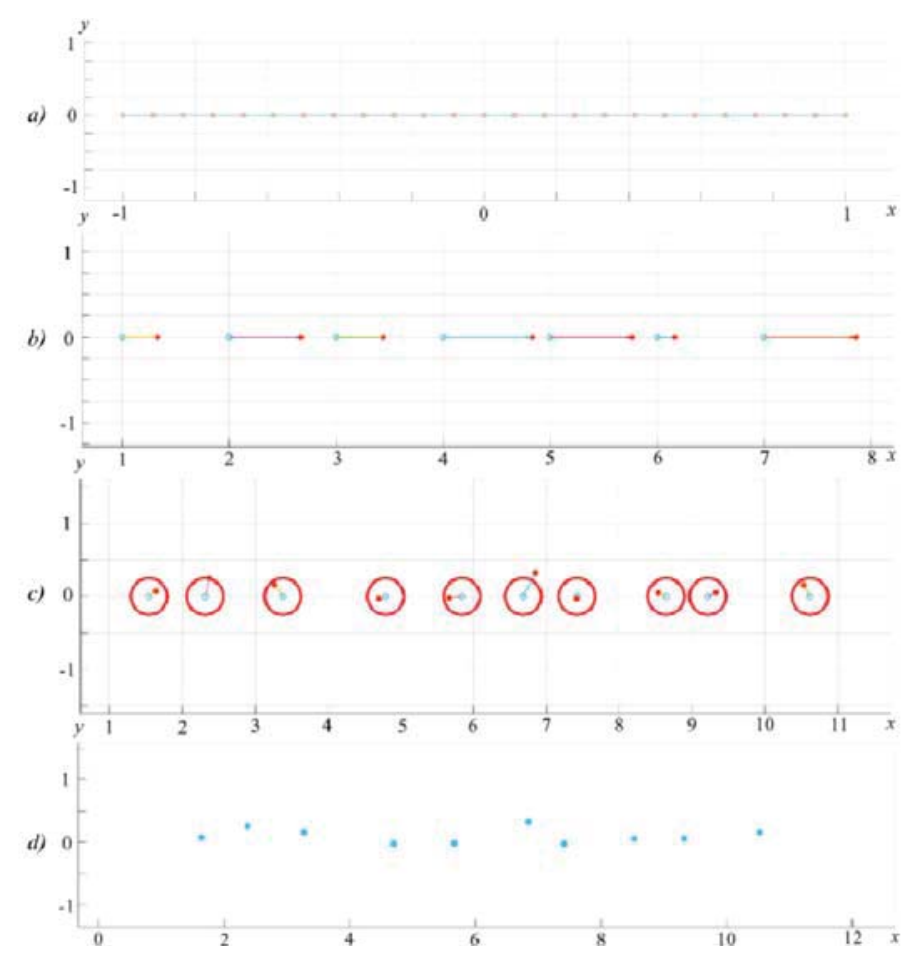

Figure 4. Subscribers' mutual placement types generation algorithm (using "chain" as an example)

After that the points are moved randomly (with uniform distribution) relative to the vector so that these points do not "touch" each other (Figure 4, b). Thus, the subscriber's location deviation from each other is simulated.

Then a random deviation with normal distribution is added to each point of the figure (Figure 2, c). Initially, the deviation simulates the subscriber's location inaccuracy the in the subscribers' mutual placement type figure and the inaccuracy of location determination methods (for example by satellite navigation systems) [6, 7]. For the subscribers the offset was set so that the deviation from the original position is 3 - 5 meters ( 6 - 10 pixels for a picture simulating the field 128 by 128 meters), as it is achievable accuracy for global positioning systems such as GPS and GLONASS [11], and another 0.5 - 1 meter to deviate the subscriber from the ideal position in the subscribers' mutual placement type figure. The processing result is shown in Figure 4 (d). The resulting figure then rotated with a random angle (Figure 3).

For further use, the resulting SMPT is recorded as a 256 to 256 elements array.

SMPT 1 - "In line" is formed of one vector. For SMPT 2 "Two lines" two collinear vectors with random distance between them (in some range) are used. The number of subscribers in the lines may differ by no more than 6 , this difference is also set randomly with uniform distribution (Figure 5). 


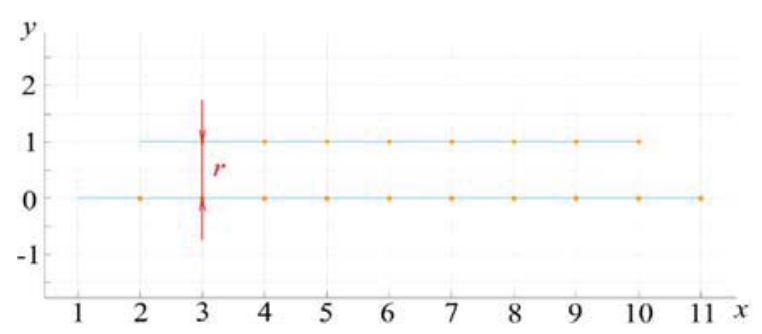

Figure 5. Subscribers' mutual placement type 2 - "Column of two". The distance $r$ is equal to one, i.e. the initial distance between the points in one line
To get the SMPT 3 "Ring" subscribers are selected on a circle, to obtain a circular subscribers' mutual placement type, then the formation is randomly compressed or stretched (Figure 6, a) along one of the axes. During next step the SMPT points are randomly offset and the figure is rotated by a random angle. The result is shown in Figure 6 (b)

For SMPT 4 - "Crowd" a random number of points in a certain range created. Then noise with a large value is added to the points to simulate a random crowding (Figure 7).
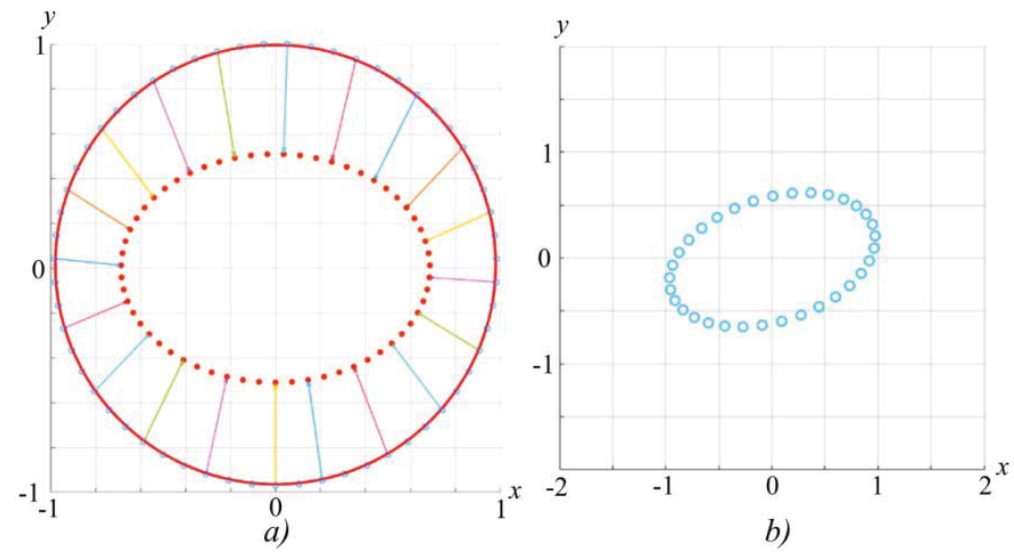

Figure 6. Subscribers' mutual placement type 3 «Ring». The points are selected on a circle, moved along it by the same way as the previous figure types, then the shape is accidentally compressed or stretched along one of the axes and rotated by a random angle

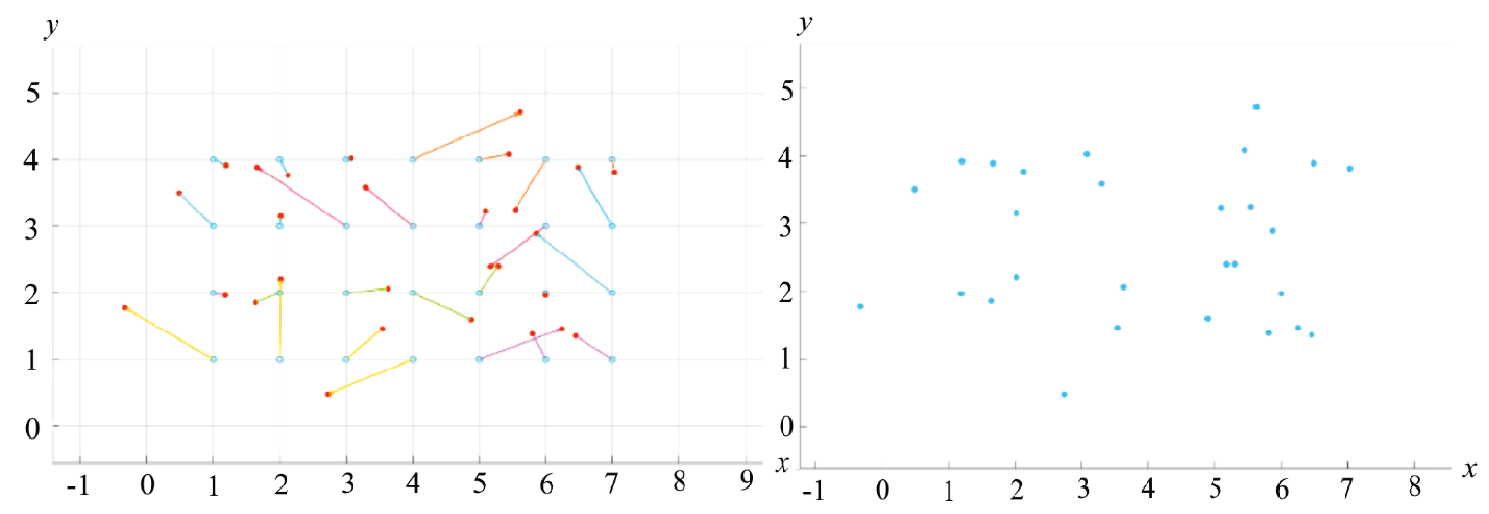

Figure 7. Subscribers’ mutual placement type 4 «Crowd».
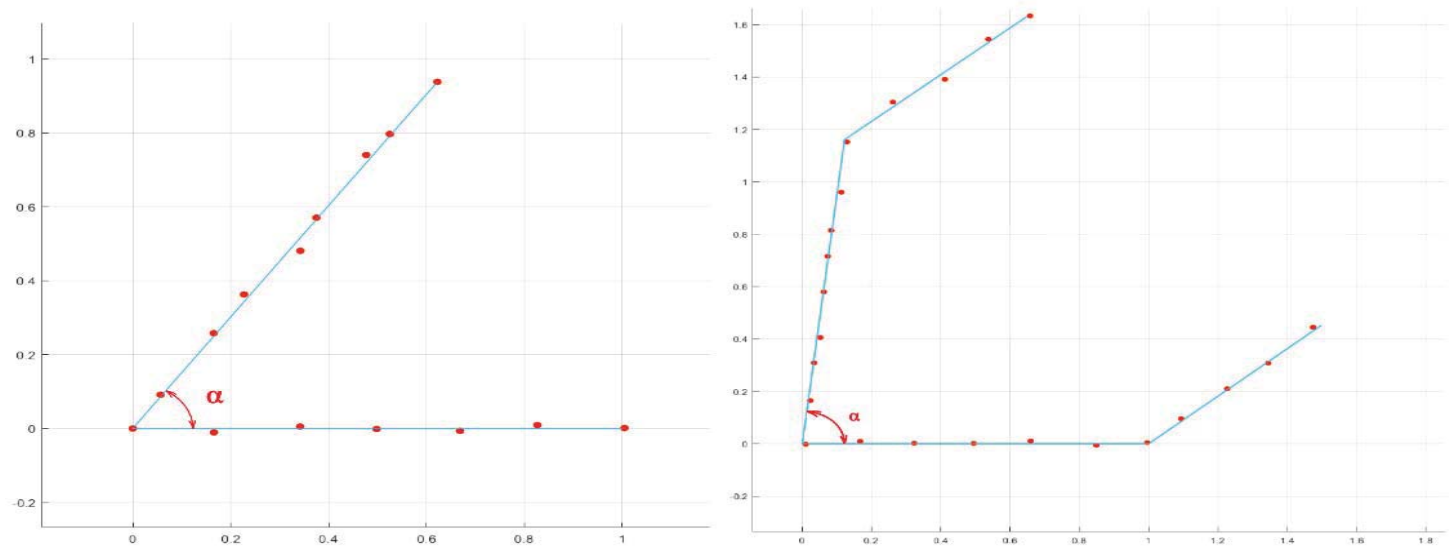

Figure 8. Subscribers’ mutual placement type 5 «Wedge» and 6 «Wedge 2».

The angle $\alpha$ is given randomly with uniform distribution in the range from $30^{\circ}$ to $90^{\circ}$ 
For SMPT 5 - "Wedge" 2 vectors are created, one of them is rotated by a random angle in the range from $30^{\circ}$ to $90^{\circ}$ with uniform distribution. The number of subscribers in the lines may differ in the same way as in SMPT 2 - "Two lines". To create SMPT 6 - "Wedge 2" four vectors are created, the angle, as well as for SMPT 5 - "wedge" is set in the range from $30^{\circ}$ to $90^{\circ}$ with uniform distribution (Figure 8).

Subscribers' mutual placement type 7 "Corridor" is created from 2 to 6 vectors. Vectors are divided into groups, are shifted relative to each other by analogy with subscribers' mutual placement type 2, groups of vectors are shifted relative to each other group in the same way (Figure 9).

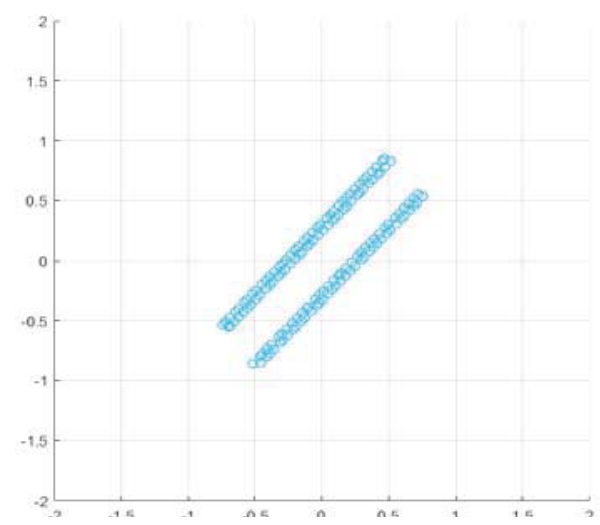

Figure 9. Subscribers’ mutual placement type 7 «Corridor»

Subscribers' mutual placement type 8 "Shuttle" is built in the same way as formation 3 "Ring", with the difference that from 3 to 8 points inside the circle are also created for SMPT 8. The next created subscribers' mutual placement types (9 - "Square", 10 - "Bowl", 11 - "Turtle") are similar to the previous created types (Figure 10).
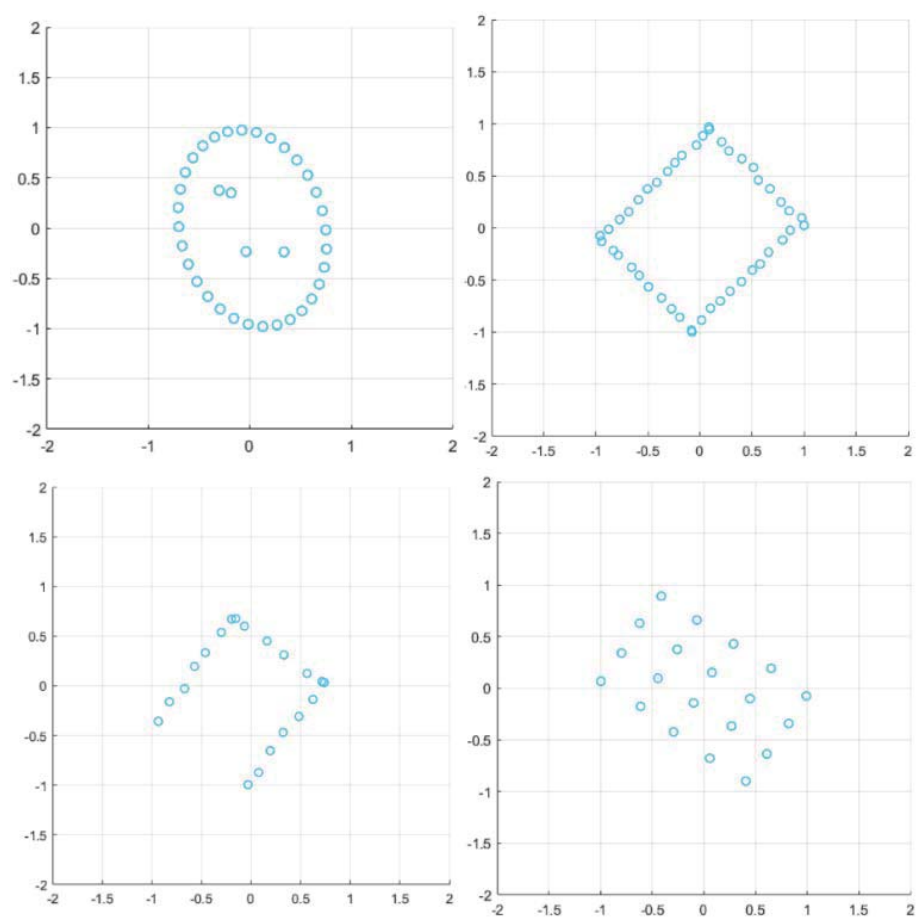

Figure 10. Subscribers' mutual placement types 8 «Shuttle», 9 "Square", 10 "Bowl", 11 "Turtle"
Thus, the algorithm for generating SMPT can be presented as the following block diagram (Figure 11).

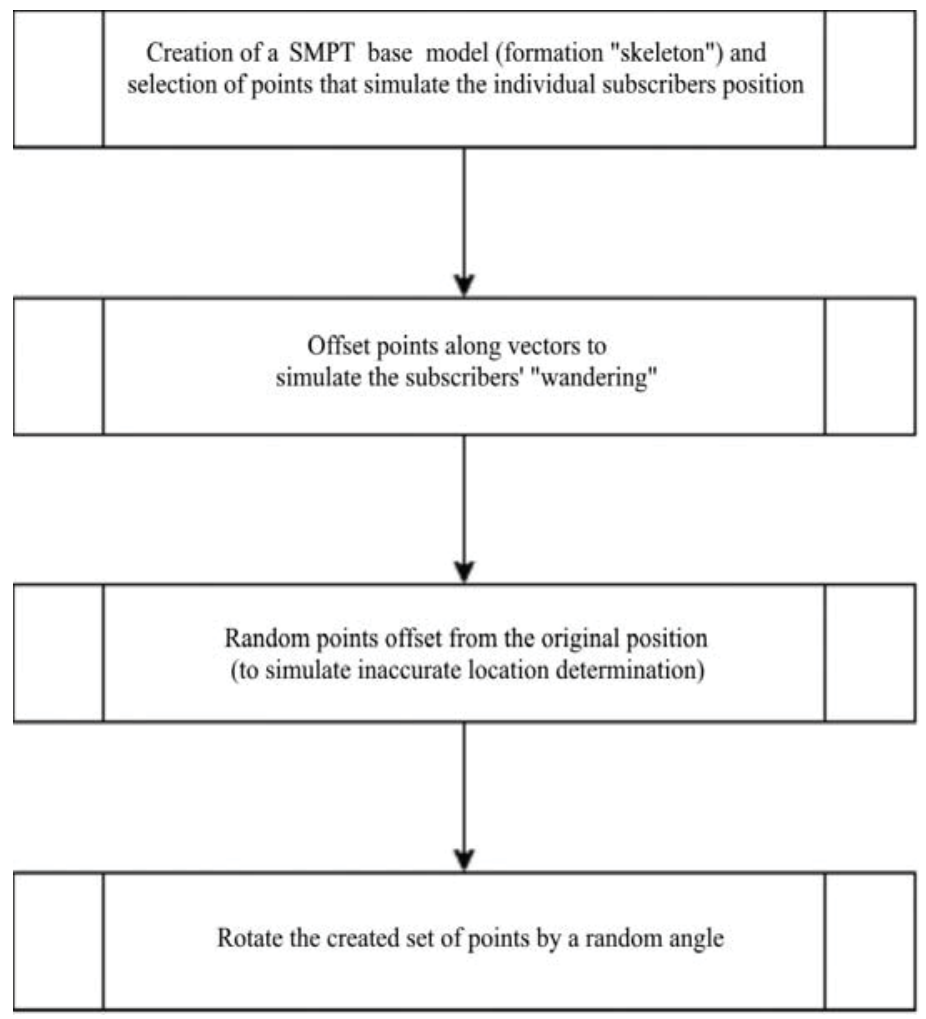

Figure 11. SMPT generation algorithm model block diagram

The result of all transformations is a dataset used for the neural network training. A lot of examples of "distorted" SMPT implementations are further used for convolution neural network training and testing, training and control sets size optimization.

\section{Neural network training}

The convolutional neural networks were successfully used for the recognition of a limited set of SMPTs in paper [1]. Based on the paper [1] results, the convolutional neural network [12, 13, 14] was also chosen to estimate the recognition possibility of an extended set of simulated SMPTs in this paper. The convolutional neural network diagram is shown in Figure 12.

In the chosen convolutional neural network configuration, the input layer is 256 by 256 points. The images are represented as a 256x256 array with values 0 and 255 ( 0 as the background and 255 as a point).

All the neural network layers. except for the input and output. are called hidden layers. The first hidden layer produces a subsampling of the input image. The layer consists of sixteen feature maps, each consisting of an array of 256 by 256 neurons. Each neuron is obtained from 3 by 3 synaptic kernels. The number of filters of the first layer (sub-sampling) was chosen to be quite large (64 filters). The activation function ReLU (Rectified linear unit) [17] was used for the hidden layers that produce convolution. The activation function (is a transfer function of the neuron) determines the dependence of the neuron output signal on the input signal [18]. 

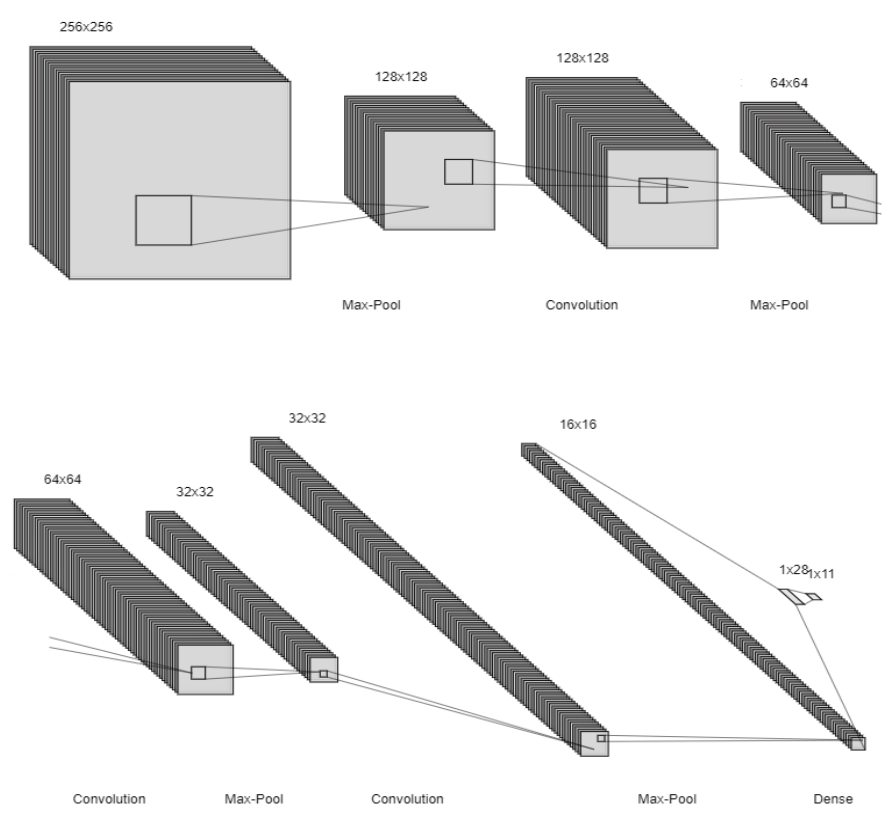

Figure 12. The convolutional neural network diagram

The second hidden layer performs convolution and local averaging. It consists of 64 feature maps, but each of the next layer's maps will contain 128 by 128 neurons. Each neuron is obtained of 5 by 5 synaptic kernels, the calculation of its value includes training (synaptic) coefficients, layer shift coefficients and linear activation function (ReLU).

The third hidden layer produces a second subsample. It generates 128 feature maps, each of which consists of 64 by 64 neurons.

Since the computational layers are divided into 2 types (subsampling and convolutional), the model will be set in a "bipyramidal" order. This order is described as that on each convolutional and subsample layer the number of feature maps increases with decreasing resolution of each map relative to the previous layer. The meaning of the subsample following the convolution, is to "simplify" the feature map from a more "complex" one, which has a larger dimension $[18,19]$.

Training samples for each type of mutual placement are generated randomly, i.e. each sample of one SMPT differs from another sample of this type by the number of points (mobile network subscribers) defined in some range, random angle of rotation, etc. Also, the points' coordinates in each sample are distorted by noise, randomly shifting the points relative to their original position by a distance not more than the specified (with normal distribution) to simulate the inaccuracy of subscribers' location determination, as well as the imitation of movement - subscribers "deviation" off the exact position in the example.

For network training, 40007 samples of subscriber location types were created, consisting of 11 variants shown in Figure 2. This number of examples is enough to represent the majority of possible variations of each type subscribers' mutual placement.

\section{Results analysis}

On the neural network training graphics (figure 13) it can be noticed that the smallest training loss value is achieved on 6-7 training epoch, and test sample classification accuracy ceases to grow. However, the learning sample classification accuracy is growing with train set loss value continue to drop. This is because the neural network "remembers" the learning sample [20], and further training the will not improve the quality of this neural network, thus, ways to solve the described convolutional neural network optimization problem should be considered in the future to improve the quality of its performance.
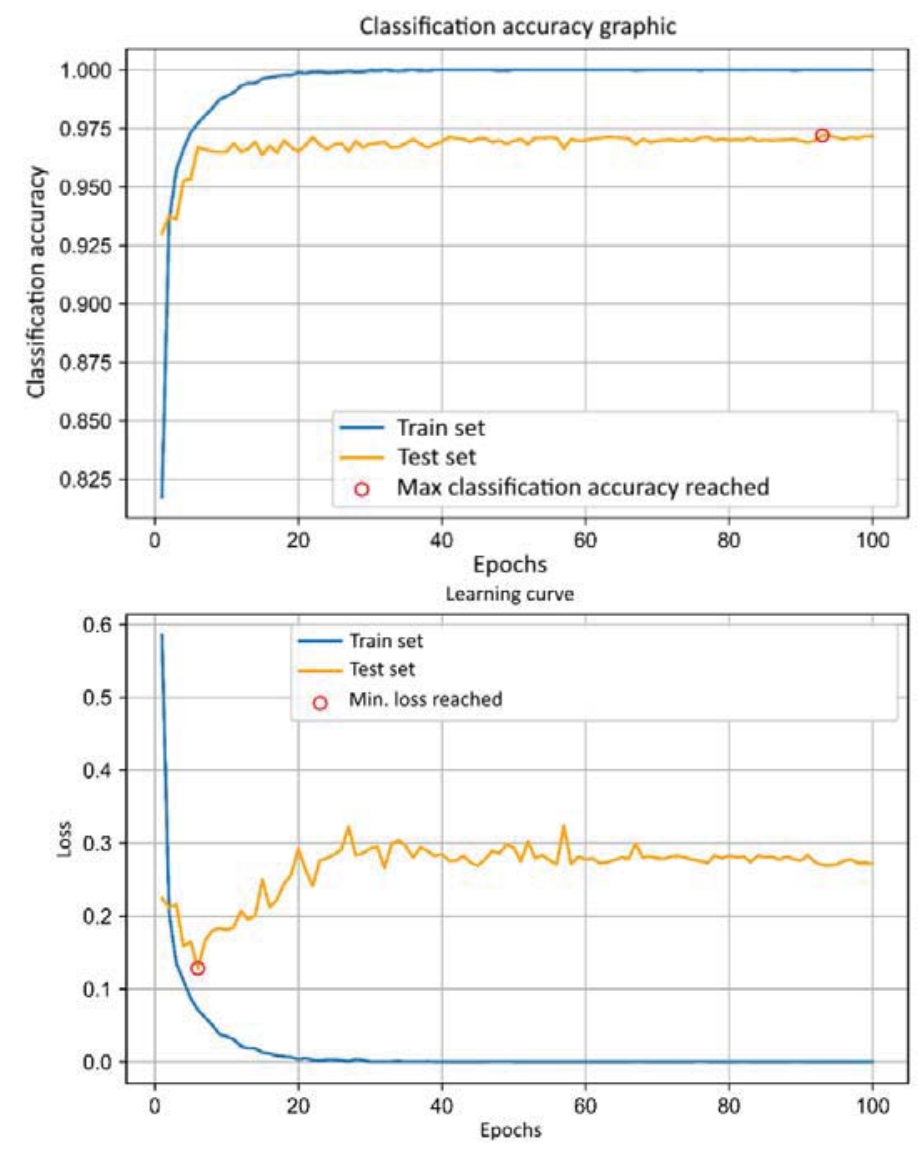

Figure 13. The neural network training plots (classification accuracy by epochs / loss values be epochs)

The learning time of one epoch is 692 seconds, the recognition time of 1000 new examples is $\sim 945$ seconds. The described convolutional neural network has a total of 4,292,438 connection weights between neurons (synapses). The smallest achieved value of training error is 0.128 , the best probability of correct SMPT recognition from the test set has reached 0.972 .

Since the chosen architecture of convolutional neural network has a sufficiently large neurons number and large value of connections between them, the problem of speed inevitably rises. The necessity to process dozens and hundreds of subscribers' mutual placement types examples in real time leads to the task of finding an effective hardware convolutional neural networks implementation. Existing solutions analysis has shown that it is reasonable to use superconductor [21] as a basic technology and implement neurons on adiabatic Josephson cells [22]. This approach will provide the necessary performance speed by performing calculations at a high clock frequency (typical clock frequencies for Josephson cells are about $100 \mathrm{GHz}$ ), as well as calculate the value of neuron activation functions per each clock, which will greatly increase the speedup compared to the classical neural networks' schemes. 


\section{Conclusions}

The mathematical model proposed in the paper allows creating a representative training and test sets for training and testing the neural network. The convolution neural network trained on these samples has shown high results of classification accuracy. Thus, the results of [1] are generalized for a wider class of subscribers' mutual placement types. A deeper investigation of the influence of the neural network learning parameters on the recognition results is planned in the future. This will allow us to optimize the convolution neural network structure, speed and recognition quality.

\section{References}

1. Tereshonok M.V., Rautkin Yu.V. (2018). Estimation and forecasting of mass events participants activities using the intellectual analysis of mobile communication network traffic parameters. Voprosy Kiberbezopasnosti. No. 3(27). P. 70-76.

2. Merkle R.C. (1978). Secure communications over insecure channels. Communications of the ACM, 21(4). P. 294-299.

3. Diffie W. and Hellman M. (1976). New directions in cryptography. IEEE transactions on Information Theory, 22(6). P. 644-654.

4. Adjemov, S.S., Klenov, N.V., Tereshonok, M.V. and Chirov, D.S. (2016). A neural-network method for the synthesis of informative features for the classification of signal sources in cognitive radio systems. Moscow University Physics Bulletin, 71(2). P.174-179.

5. Tereshonok M.V. (2016). Model ocenki haraktera deiatel'nosti grupp abonentov setei' mobil’noi` sviazi. Tekhnologii informatcionnogo obshchestva - X Mezhdunarodnaia otraslevaia nauchno-tekhnicheskaia konferentciia: sbornik trudov. Moscow. Media Publisher. P. 156.

6. Tereshonok M.V., Altukhov E.V. (2017). Situational analysis of mass events with the help of intelligent analysis of service commands of mobile communication networks when subscribers use Internet messengers. Fundamental problems of radioelectronic instrument making. Vol. 17. No. 4. P. 897-900.

7. Vinogradov A.N., Tereshonok M.V. (2014). Features of approach to contemporary radio monitoring software development. TComm. Vol. 8. No. 9. P. 36-38.

8. Ziiadinov V.V., Tereshonok M.V. (2020). Matematicheskie modeli i metody` raspoznavaniia vzaimnogo raspolozheniia mobil`ny`kh abonentov. Tekhnologii informatcionnogo obshchestva. Sbornik trudov XIV Mezhdunarodnoi otraslevoi nauchnotekhnicheskoi konferentcii. P. 157-159.
9. Tereshonok M.V. (2008). Poisk assotciativny `kh pravil pri analize zagruzki setei sotovoi`sviazi. E`lektrosviaz`. No. 6. P. 32-33.

10. Adzhemov S.S., Tereshonok M.V., Chirov D.S. (2009). Optimizatciia algoritmov poiska ustoi chivy kh grupp abonentov sistem mobil`noi`radiosviazi. T-Comm. No. S6. P. 14-15.

11. Zheng W., Huang X. and Li Y. (2017). Understanding the tourist mobility using GPS: Where is the next place? Tourism Management. Vol. 59. P. 267-280.

12. Roetman J. (2020). Using WiFi Signals in Combination with GPS to Track Human Traffic in a Space (No. 3902). EasyChair.

13. Renfro B.A., Stein M., Boeker N. and Terry A. (2018). An analysis of global positioning system (GPS) standard positioning service (SPS) performance for 2017. See https://www. gps. gov/systems/gps/performance/2014-GPS-SPS-performance-analysis. pdf.

14. CS231n Convolutional Neural Networks for Visual Recognition. URL: https://cs231n.github.io/convolutional-networks/; Retrieved Nov 252020.

15. Plokhyh G.I. (2014). Spetsyal'naya podgotovka sotrudnikov organov vnetrennykh del. Ucheb. Posobie. Kursk: Yugo-Zap. Gos. un-t. $350 \mathrm{p}$.

16. Land Warfare Doctrine 3-0-3, Land Tactics (Developing Doctrine). 2009. Austra Army. URL https://www.army.gov.au/sites/default/files/lwd_3-0-

3_formation_tactics.pdf?acsf_files_redirect; Retrieved Dec 12, 2020.

17. Nair V. and Hinton G.E. (2010), January. Rectified linear units improve restricted boltzmann machines. In ICML.

18. Hinkelmann, K., Neural Networks, p. 7. University of Applied Sciences Northwestern Switzerland. http://didattica. cs. unicam. it/lib/exe/fetch. php.

19. Hubel D.H. and Wiesel T.N. (1962). Receptive fields, binocular interaction and functional architecture in the cat's visual cortex. The Journal of physiology, 160(1), p.106.

20. Julien Despois. Memorizing is not learning! -6 tricks to prevent overfitting in machine learning. URL: https://hackernoon.com/memorizing-is-not-learning-6-tricks-to-preventoverfitting-in-machine-learning-820b091dc42 Retrieved Oct 172020.

21. Klenov N.V., Kuznetsov A.V., Schegolev A.E., Soloviev I.I., Bakurskiy S.V., Kupriyanov M.Y. and Tereshonok M.V. (2019). A neuron based on a single flux qubit. Low Temperature Physics, 45(7). P. 769-775

22. Soloviev I.I., Schegolev A.E., Klenov N.V., Bakurskiy S.V., Kupriyanov M.Y., Tereshonok M.V., Shadrin A.V., Stolyarov V.S. and Golubov A.A. (2018). Adiabatic superconducting artificial neural network: Basic cells. Journal of applied physics, 124(15). P. 152113. 


\title{
МАТЕМАТИЧЕСКИЕ МОДЕЛИ И МЕТОДЫ ОЦЕНКИ ВЗАИМНОГО РАСПОЛОЖЕНИЯ МОБИЛЬНЫХ АБОНЕНТОВ
}

\author{
Зиядинов Вадим Валерьевич, Московский технический университет связи и информатики, Москва, Россия, \\ willwillson I3@gmail.com
}

Терешонок Максим Валерьевич, Московский технический университет связи и информатики, Москва, Россия, tereshonok@srd.mtuci.ru

\section{Аннотация}

Цель статьи заключается в создании математической модели типов взаимного расположения абонентов сетей мобильной связи, применимой для систем автоматизации прогнозирования характера деятельности абонентов. Метод исследования заключался в разработке математической имитационной модели для генерации множества псевдослучайных примеров типов взаимного расположения абонентов, создании с помощью разработанной модели обучающей выборки, обучении свёрточной нейронной сети и использовании результатов её обучения для распознавания новых примеров типов взаимного расположения абонентов. Полученные результаты. Предложена математическая модель, позволяющая создать репрезентативную обучающую и контрольную выборку типов взаимного расположения абонентов сетей мобильной связи для обучения и тестирования нейронной сети. Обученная с использованием этих выборок свёрточная нейронная сеть показала высокие результаты точности классификации широкого класса типов взаимного расположения абонентов.

Ключевые слова: нейронные сети, взаимное расположение абонентов, позиционирование, классификация, распознавание форм.

\section{Литература}

І. Терешонок, М.В. Рауткин, Ю.В., Оценка и прогнозирование деятельности участников массовых мероприятий с помощью интеллектуального анализа параметров трафика сетей мобильной связи // Вопросы кибербезопасности, (3 (27)). 2018.

2. Merkle, R.C. I Secure communications over insecure channels // Communications of the ACM, 2I(4), 1978. C. $294-299$.

3. Diffie, W. and Hellman, M., New directions in cryptography // IEEE transactions on Information Theory, 1976, 22(6), pp.644-654.

4. Adjemov, S.S., Klenov, N.V., Tereshonok, M.V. and Chirov, D.S., A neural-network method for the synthesis of informative features for the classification of signal sources in cognitive radio systems // Moscow University Physics Bulletin, 2016, 7I(2), PP. I74-I79.

5. Терешонок М.В. Модель оценки характера деятельности групп абонентов сетей мобильной связи / В сборнике: Технологии информационного общества // Х Международная отраслевая научно-техническая конференция: сборник трудов. 2016. С. I56.

6. Терешонок, М.В. Алтухов, Е.В. Ситуационный анализ массовых мероприятий с помощью интеллектуального анализа служебных команд сетей мобильной связи при использовании абонентами интернет-мессенджеров // Фундаментальные проблемы радиоэлектронного приборостроения, 2017, 17(4), рР. 897-900.

7. Виноградов А.Н., Терешонок М.В. Особенности проектирования программного обеспечения современного комплекса мониторинга радиоэфира // Т-Сотm: Телекоммуникации и транспорт. 2014. Т. 8. № 9. С. 36-38.

8. Зиядинов В.В., Терешонок М.В. Математические модели и методы распознавания взаимного расположения мобильных абонентов // В сборнике: Технологии информационного общества. Сборник трудов XIV Международной отраслевой научно-технической конференции. 2020. С. 157-І59.

9. Терешонок М.В. Поиск ассоциативных правил при анализе загрузки сетей сотовой связи // Электросвязь. 2008. № 6. С. 32-33.

10. Аджемов С.С., Терешонок М.В., Чиров Д.С. Оптимизация алгоритмов поиска устойчивых групп абонентов систем мобильной радиосвязи // Т-Сomm: Телекоммуникации и транспорт. 2009. № S6. С. I4-I5.

II. Zheng, W., Huang, X. and Li, Y. Understanding the tourist mobility using GPS: Where is the next place? // Tourism Management, 20I7,

59, Pp. 267-280.

12. Roetman, J. Using WiFi Signals in Combination with GPS to Track Human Traffic in a Space (No. 3902). 2020, EasyChair.

13. Renfro, B.A., Stein, M., Boeker, N. and Terry, A. 20I8. An analysis of global positioning system (GPS) standard positioning service (SPS) performance for 2017. See https://www. gps. gov/systems/gps/performance/20I4-GPS-SPS-performance-analysis. pdf.

14. CS23In Convolutional Neural Networks for Visual Recognition. URL: https://cs23In.github.io/convolutional-networks/; Retrieved Nov 252020.

15. Плохих, Г.И. Специальная подготовка сотрудников органов внутренних дел. уче6. пособие. Курск: Юго-Зап. Гос. ун-т, 20І4, p. 350 .

16. Land Warfare Doctrine 3-0-3, Land Tactics (Developing Doctrine). 2009. Australian Army. URL: https://www.army.gov.au/sites/default/files/Iwd_3-0-3_formation_tactics.pdf?acsf_files_redirect; Retrieved Dec I2, 2020.

17. Nair, V. and Hinton, G.E., 2010, January. Rectified linear units improve restricted boltzmann machines. In ICML.

18. Hinkelmann, K., Neural Networks, p. 7. University of Applied Sciences Northwestern Switzerland. http://didattica. cs. unicam. it/lib/exe/fetch. php.

19. Hubel, D.H. and Wiesel, T.N. Receptive fields, binocular interaction and functional architecture in the cat's visual cortex. The Journal of physiology, 1962, 160(I). P. 106.

20. Julien Despois. Memorizing is not learning! - 6 tricks to prevent overfitting in machine learning. URL: https://hackernoon.com/memorizing-is-not-learning-6-tricks-to-prevent-overfitting-in-machine-learning-820b09Idc42 Retrieved Oct 172020.

2I. Klenov, N.V., Kuznetsov, A.V., Schegolev, A.E., Soloviev, I.I., Bakurskiy, S.V., Kupriyanov, M.Y. and Tereshonok, M.V. A neuron based on a single flux qubit // Low Temperature Physics, 2019, 45(7). C. 769-775.

22. Soloviev, I.I., Schegolev, A.E., Klenov, N.V., Bakurskiy, S.V., Kupriyanov, M.Y., Tereshonok, M.V., Shadrin, A.V., Stolyarov, V.S. and Golubov, A.A. Adiabatic superconducting artificial neural network: Basic cells // Journal of applied physics, 2018, I24(I5). C. I52II3.

Информация об авторах:

Зиядинов Вадим Валерьевич, инженер, Московский технический университет связи и информатики (МтУСИ), Москва, Россия

Терешонок Максим Валерьевич, заведующий лабораторией, Московский технический университет связи и информатики (МТУСИ), доцент, д.т.н., Москва, Россия 